Dikirim: 14 Juli 2017 Diterbitkan: 15 Maret 2018

\section{Usia pubertas dan citra tubuh terhadap perilaku seksual pranikah pada remaja putri di Yogyakarta}

\section{Age of puberty and body image to premarital sexual behavior in female adolescent In Yogyakarta}

Rihul H Juliyatmi ${ }^{1}$, Toto Sudargo ${ }^{2}$, Djauhar Ismail ${ }^{3}$

\begin{abstract}
Purpose: The purpose of this study was to identify the relationship between age of puberty and body image with premarital sexual behavior in young women in Yogyakarta. Method: Observational research with cross-sectional design using quantitative and qualitative approach was conducted involving 206 students in Vocational High School Yogyakarta with sampling technique purposive sampling. Results: Twenty-eight percent of teenagers are at risk of premarital sexual behavior. The age of puberty and body image has no significant relationship with premarital sexual behavior in adolescents $p>0.05$. Media information and peers gives the most influence to age of puberty relationship with premarital sexual behavior. Media information gives the most influence on the relationship of body image with premarital sexual behavior. Conclusion: This research suggests the need for policy of media content information arrangement as a positive body image promotion media. Need to form peer education to prevent premarital sexual risk behavior.
\end{abstract}

Keywords: adolescent; age of puberty; body image; premarital sexual behavior

\footnotetext{
${ }^{1}$ Departemen Biostatistik, Epidemiologi dan Kesehatan Populasi, Fakultas Kedokteran, Kesehatan Masyarakat dan Keperawatan, Universitas Gadjah Mada (Email: rihul.juli@gmail.com)

${ }^{2}$ Departemen Gizi Kesehatan, Fakultas Kedokteran, Kesehatan Masyarakat dan Keperawatan, Universitas Gadjah Mada

${ }^{3}$ Departemen Ilmu Kesehatan Anak, Fakultas Kedokteran, Kesehatan Masyarakat dan Keperawatan, Universitas Gadjah Mada
} 


\section{PENDAHULUAN}

Masa remaja merupakan masa transisi kehidupan terpenting yang didorong oleh perkembangan biologis. Remaja akan mengalami masa pubertas meliputi perkembangan sosial, emosional, dan perkembangan seksual (1). Salah satu perkembangan seksual pada masa ditandai dengan mulai mengenal perilaku seksual pranikah (2).

Center for disease control (CDC) tahun 2015 melaporkan 39,8\% siswa perempuan sekolah menengah atas (SMA) di Amerika Serikat pernah melakukan hubungan seksual. Sedangkan di Kentucky, sebesar 41,4\% siswi SMA pernah melakukan hubungan seksual. Selain siswa SMA, didapatkan juga sebesar 9,9\% siswa sekolah menengah pertama (SMP) di Kota Miami-Dade, Florida pernah melakukan hubungan seksual (3).

Survei BKKBN tahun 2011 menunjukkan 71\% remaja di Indonesia mengaku pernah berpacaran. Perilaku seksual yang dilakukan selama berpacaran adalah berpegangan tangan (88\%), ciuman bibir (32\%), merangsang atau meraba (11\%), serta melakukan hubungan seksual pada remaja putri (2\%) dan remaja putra (5\%). Sembilan puluh persen hubungan seksual dilakukan bersama pacar, dan $10 \%$ dilakukan dengan teman dan pekerja seks komersial (4).

Hasil survei kesehatan reproduksi remaja propinsi Daerah Istimewa Yogyakarta tahun 2011 menunjukkan, terdapat $77,98 \%$ remaja pernah memiliki pengalaman berpacaran. Tingkat berpacaran remaja di SD dan SMP mencapai 73,93\%, sementara untuk tingkat SMA dan Diploma mencapai 84,21\%. Perilaku seksual yang dila- kukan selama berpacaran adalah $88,70 \%$ berpegangan tangan atau berpelukan, sebanyak 49,17\% ciuman bibir, $13,29 \%$ pernah menyentuh alat kelamin pacar, dan 12,29\% pernah melakukan hubungan seksual dengan pacar (5).

Beberapa penelitian memperoleh bahwa usia pubertas merupakan salah satu faktor risiko perilaku seksual pranikah remaja. Sebuah studi meta analisis dari tahun 1980 sampai tahun 2012 mempelajari keterkaitan antara usia pubertas dan usia menarche dengan perilaku seksual berisiko di kalangan remaja berusia 10,5 tahun sampai 22,4 tahun. Studi menunjukkan bahwa remaja dengan usia pubertas lebih awal cenderung melakukan perilaku seksual berisiko, hal tersebut lebih sering ditemukan pada remaja tahap awal (6). Remaja dengan usia pubertas lebih awal memiliki aktivitas seksual lebih tinggi dibandingkan dengan remaja dengan usia pubertas yang terlambat (7).

Perubahan pada remaja terutama pada perubahan fisik, mendorong remaja berkeinginan memiliki bentuk tubuh ideal serta memberikan penilaian tertentu pada bentuk tubuh mereka. Perubahan emosional membuat remaja tertarik dengan lawan jenis, yang mendorong perilaku berpacaran (7).

Remaja dengan citra tubuh positif memiliki kepercayaan diri yang tinggi, cenderung lebih sering melakukan hubungan seksual tanpa kondom dibandingkan remaja dengan citra tubuh negatif (8). Sebuah survei menunjukkan bahwa kepuasan citra tubuh dikaitkan dengan kenyamanan yang lebih besar dengan tubuh seseorang selama aktivitas seksual, frekuensi yang lebih tinggi dari perilaku seksual, termasuk peningkatan inisiasi aktivitas seksual oleh perempuan, serta peningkatan frekuensi orgasme (9).

Individu yang puas dengan penampilan diri lebih merasa nyaman dan terlibat dalam perilaku seksual. Tidak menutup kemungkinan bahwa perasaan individu tentang perubahan penampilan terjadi setelah terlibat perilaku seksual. Remaja laki-laki lebih puas dengan penampilan mereka setelah hubungan seksual pertama, sedangkan remaja perempuan menjadi sedikit kurang puas dengan penampilan mereka setelah melakukan hubungan seksual pertama $(10,11)$. Belum ada penelitian yang mengaitkan usia pubertas dan citra tubuh dengan perilaku seksual remaja. Penelitian ini bertujuan untuk mengetahui pengaruh usia pubertas dan citra tubuh terhadap perilaku seksual pranikah pada remaja putri di Yogyakarta.

\section{METODE}

Penelitian cross-sectional dilakukan dengan pendekatan kuantitatif dan kualitatif. Variabel bebas penelitian adalah usia pubertas dan citra tubuh. Variabel terikat adalah perilaku seksual pranikah, Media informasi, teman sebaya, status sosial ekonomi sebagai variabel luar. Sampel penelitian adalah siswi SMK Kota Yogyakarta yang memenuhi kriteria inklusi dan eksklusi. Teknik pengambilan sampel menggunakan nonprobability sampling dengan metode purposive sampling. Sampel penelitian adalah remaja putri yang memenuhi klriteria inklusi dan ekslusi. Kriteria inklusi adalah siswi yang bersedia mengikuti penelitian, sedangkan kriteria eksklusi adalah siswi yang tidak hadir saat pengambilan data. Pengambilan sampel dilakukan di Kota Yogyakarta dengan sampel 206 responden.

Perilaku seksual pranikah diukur menggunakan kuesioner dari SKRRI dan penelitian terdahulu (12). Usia pubertas diukur menggunakan Pubertal Development Scale (13). Citra tubuh diukur menggunakan kuesioner Physical and Trait Anxiety Scale(14). 
Paparan media informasi menggunakan kuesioner dan kategori modifikasi (12). Pengaruh teman sebaya diukur meng- gunakan kuesioner dan kategori modifikasi dari Patient Acuity Category Scale (PACS) (15). Status sosial ekonomi diukur berdasarkan acuan Badan Koordinasi Keluarga Berencana (BKKBN) tahun 2007 (16).

Analisis yang digunakan adalah analisis bivariabel menggunakan chi square test dengan derajat kepercayaan 95\% confidence interval. Analisis multivariabel digunakan untuk mengontrol variabel luar. Uji statistik yang digunakan adalah regresi logistik. Analisis kualitatif dengan wawancara mendalam yang bertujuan untuk melengkapi data kuantitatif dengan menggali lebih dalam tentang perilaku seksual pranikah. Tahapan mengambil data kualitatif adalah mereduksi data dan dilanjutkan dengan penyajian data dan diakhiri dengan penarikan kesimpulan.

\section{HASIL}

Tabel 1 menunjukkan lebih dari 20\% responden berperilaku seksual pranikah berisiko.

Tabel 1. Ciri remaja putri SMK di Yogyakarta

\begin{tabular}{lr}
\hline Ciri responden & \% (n=206) \\
\hline Perilaku seksual pranikah & \\
Berisiko(n=58) & 28,16 \\
Tidak Berisiko (n=148) & 71,84 \\
Usia pubertas & \\
Normal (n=165) & 80,10 \\
Terlambat (n=41) & 19,90 \\
Citra tubuh & \\
Puas (n=129) & 62,62 \\
Tidak puas(n=77) & 37,38 \\
Media informasi & \\
Sering terpapar (n=54) & 26,21 \\
Jarang terpapar (n=152) & 73,79 \\
Teman sebaya & \\
Ada (n=66) & 32,04 \\
Tidak ada (n=140) & 67,9 \\
Status sosial ekonomi & \\
Rendah (n=51) & 31,55 \\
Tinggi (n=141) & 68,45 \\
\hline
\end{tabular}

Tabel 2 menunjukkan variabel bebas usia pubertas dan variabel luar status sosial ekonomi tidak memiliki hubungan yang signifikan dengan perilaku seksual pranikah. Variabel bebas citra tubuh serta variabel luar media informasi dan teman sebaya memiliki hubungan yang signifikan dengan perilaku seksual pranikah. Responden yang merasa puas terhadap citra tubuh memiliki risiko 2 kali lebih besar berperilaku seksual pranikah dibandingkan dengan responden yang merasa tidak puas terhadap citra tubuh.

Tabel 2. Odds ratio perilaku seksual pranikah remaja

\begin{tabular}{lccccc}
\hline \multicolumn{1}{c}{ Variabel } & $\begin{array}{c}\text { Berisiko } \\
\text { (\%) }\end{array}$ & $\begin{array}{c}\text { Tidak } \\
\text { Berisiko } \\
\text { (\%) }\end{array}$ & $\boldsymbol{X}^{\mathbf{2}}$ & OR & CI 95\% \\
\hline $\begin{array}{l}\text { Usia pubertas } \\
\text { Normal }\end{array}$ & 23,30 & 56,80 & 0,37 & 1,27 & $0,58-2,80$ \\
$\begin{array}{l}\text { Terlambat } \\
\text { Citra tubuh }\end{array}$ & 4,85 & 15,05 & & & \\
$\begin{array}{l}\text { Puas } \\
\text { Tidak puas }\end{array}$ & 20,87 & 41,75 & 4,74 & 2,07 & $1,05-4,05^{*}$ \\
Media Informasi & 7,28 & 30,10 & & & \\
$\begin{array}{l}\text { Sering terpapar } \\
\text { Jarang terpapar }\end{array}$ & 11,16 & 15,05 & 7,19 & 2,48 & $1,28-4,79^{*}$ \\
Teman sebaya & 16,99 & 56,80 & & & \\
$\begin{array}{l}\text { Ada } \\
\text { Tidak ada }\end{array}$ & 12,62 & 19,42 & 5,88 & 2,19 & $1,17-4,13^{*}$ \\
$\begin{array}{l}\text { Status sosial } \\
\text { ekonomi }\end{array}$ & 15,53 & 52,43 & & & \\
$\begin{array}{l}\text { Rendah } \\
\text { Tinggi }\end{array}$ & & & & & \\
\hline Keterangan: & 6,31 & 25,24 & 3,25 & 1,88 & $0,93-3,79^{*}$ \\
\hline
\end{tabular}

Keterangan: *signifikan $(\mathrm{p}<0,05)$

Pada Tabel 3 tidak ditemukan hubungan yang signifikan antara usia pubertas maupun citra tubuh dengan perilaku seksual pranikah. Usia pubertas normal dapat memprediksi perilaku seksual pranikah berisiko lebih tinggi sebesar 7,7\% dibandingkan dengan usia pubertas terlambat setelah mempertimbangkan media informasi, teman sebaya, dan status sosial ekonomi. Media informasi dan teman sebaya memberi pengaruh terbesar terhadap hubungan usia pubertas dengan perilaku seksual pranikah. Kepuasan citra tubuh dapat memprediksi perilaku seksual pranikah berisiko lebih tinggi sebesar $8,8 \%$, setelah mempertimbangkan variabel media informasi, teman sebaya dan status sosial ekonomi. Media informasi memberi pengaruh paling besar terhadap hubungan citra tubuh dengan perilaku seksual pranikah. 
Tabel 3. Analisis logistic regression hubungan antara usia pubertas, citra tubuh, media informasi, teman sebaya, dan status sosial ekonomi dengan perilaku seksual pranikah

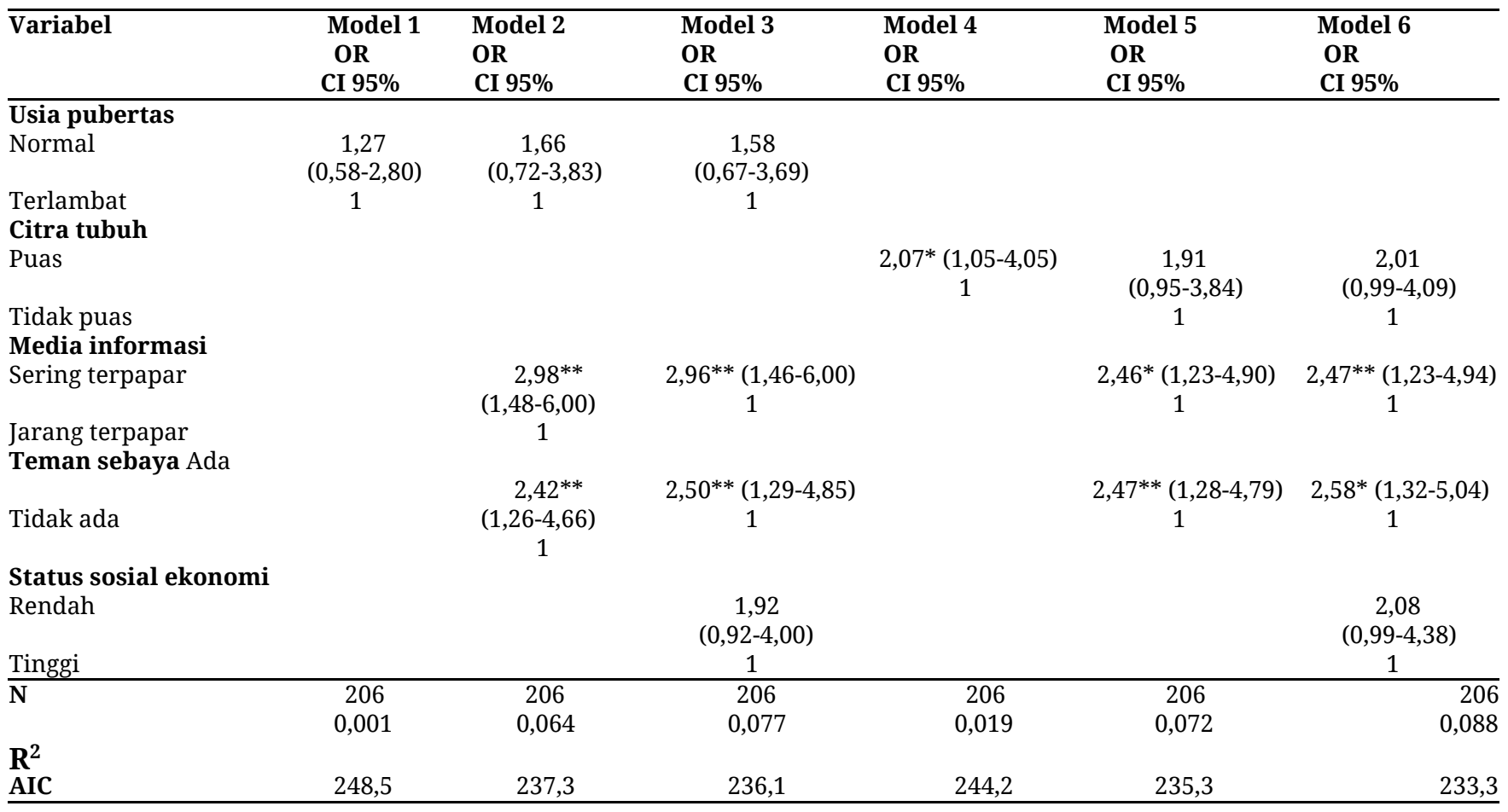

\section{BAHASAN}

Penelitian ini tidak menemukan hubungan bermakna secara statistik antara usia pubertas dengan perilaku seksual pranikah pada remaja di Kota Yogyakarta, tetapi berhubungan secara praktis. Hal ini seperti yang dikemukakan oleh De Genna et al tahun 2011 bahwa usia pubertas memiliki hubungan yang signifikan dengan perilaku seksual berisiko (17).

Penelitian ini tidak ditemukan responden yang mengalami usia pubertas dini sehingga yang dianalisis hanya responden dengan usia pubertas normal dan usia pubetas terlambat. Pertanyaan terkait usia pubertas bersifat mengingat kembali, sehingga beberapa responden mengalami kesulitan dalam mengingat usia pubertas yang dialami. Hasil analisis didapatkan bahwa remaja perempuan dengan usia pubertas normal lebih berisiko untuk melakukan perilaku seksual pranikah dibandingkan dengan remaja perempuan dengan usia pubertas terlambat. Tingkat seksual remaja dengan usia pubertas lebih awal lebih tinggi dibandingkan dengan remaja dengan usia pubertas yang terlambat (7).

Penelitian ini tidak menemukan hubungan signifikan antara citra tubuh dengan perilaku seksual pranikah setelah mengontrol variabel media informasi, teman sebaya, dan status sosial ekonomi. Hal ini serupa dengan penelitian Gillen et al bahwa citra tubuh tidak memiliki hubungan yang signifikan dengan perilaku seksual berisiko pada remaja (18). Kepuasan tinggi terhadap citra tubuh menjadi salah satu faktor protektif, sehingga remaja dengan citra tubuh tinggi memiliki perilaku seksual berisiko yang rendah.

Penelitian ini menemukan hubungan bermakna citra tubuh dengan perilaku seksual pranikah pada remaja di Kota Yogyakarta. Remaja yang merasa puas dengan citra tubuh mereka akan beresiko 2 kali lebih besar untuk melakukan perilaku seksual pranikah. Penelitian lain menemukan remaja yang merasa puas dengan citra tubuh memiliki frekuensi yang lebih besar dalam berperilaku seksual berisiko (9).

Berdasarkan analisis multivariabel, variabel media informasi terbukti memengaruhi hubungan antara usia pubertas dengan perilaku seksual pranikah, dan juga memengaruhi hubungan antara citra tubuh dengan perilaku seksual pranikah. Penelitian menemukan hubungan media informasi dengan perilaku seksual pranikah pada remaja di Kota Yogyakarta. Remaja yang sering terpapar dengan media informasi yang mengandung unsur pornografi akan berisiko lebih besar untuk melakukan perilaku seksual pranikah dibandingkan dengan remaja yang jarang terpapar.

Penelitian membuktikan media internet berkontribusi tinggi dalam perilaku seksual berisiko pada 
remaja. Remaja yang yang lebih sering mengakses media internet memiliki peluang lebih besar dalam melakukan perilaku seksual pranikah. Hal tersebut dikarenakan konten porno yang terdapat dalam media informasi dapat memberikan pengetahuan dan gambaran tentang seksualitas pada remaja sehingga cenderung akan remaja mendorong remaja tersebut berkeinginan untuk mencontoh apa yang telah dilihatnya (19).

Teman sebaya terbukti memengaruhi hubungan antara usia pubertas dengan perilaku seksual pranikah, dan juga memengaruhi hubungan antara citra tubuh dengan perilaku seksual pranikah. Analisis bivariabel pengaruh teman sebaya memiliki hubungan yang signifikan dengan perilaku seksual pranikah pada remaja. Hal ini serupa dengan penelitian Sudirman and Pradjatmo didapatkan bahwa ada hubungan yang signifikan antara peran teman sebaya dengan perilaku seksual berisiko pada remaja (20). Pengaruh negatif teman sebaya menyebabkan remaja berpeluang lebih besar melakukan perilaku seksual berisiko.

Variabel status sosial ekonomi terbukti tidak memengaruhi hubungan usia pubertas dengan perilaku seksual pranikah, dan tidak memengaruhi hubungan citra tubuh dengan perilaku seksual pranikah. Status sosial ekonomi tidak berhubungan signifikan dengan perilaku seksual pranikah. Penelitian ini menemukan remaja dengan status sosial ekonomi tinggi lebih berisiko melakukan perilaku seksual pranikah dibandingkan dengan remaja dengan status sosial ekonomi rendah. Hasil penelitian ini sejalan dengan penelitian yang dilakukan oleh Sinaga yang menyatakan bahwa tidak terdapat hubungan signifikan antara status sosial ekonomi dengan perilaku seksual pranikah (21).

\section{SIMPULAN}

Tidak terdapat hubungan antara usia pubertas dengan perilaku seksual pranikah pada remaja. Tidak terdapat hubungan yang signifikan antara citra tubuh dengan perilaku seksual pranikah pada remaja.

Media informasi dan teman sebaya memberi pengaruh terbesar terhadap hubungan usia pubertas dengan perilaku seksual pranikah. Perlu kebijakan pengaturan konten media informasi sebagai media promosi citra tubuh positif. Perlu pembentukan peer education untuk mencegah perilaku seksual berisiko pranikah.

\section{Abstrak}

Tujuan: Penelitian ini bertujuan mengetahui hubungan usia pubertas dan citra tubuh dengan perilaku seksual pranikah pada remaja putri di Yogyakarta. Metode: Penelitian observasional dengan rancangan cross sectional menggunakan pendekatan kuantitatif dan kulitatif. Besar sampel yang diambil sebanyak 206 siswi Sekolah Menengah Kejuruan di Yogyakarta dengan teknik purposive sampling. Hasil: Dua puluh delapan persen remaja berisiko melakukan perilaku seksual pranikah. Usia pubertas dan citra tubuh berhubungan signifikan dengan perilaku seksual pranikah pada remaja. Media informasi dan teman sebaya memberi pengaruh paling besar terhadap hubungan usia pubertas dengan perilaku seksual pranikah. Media informasi memberi pengaruh paling besar terhadap hubungan citra tubuh dengan perilaku seksual pranikah. Simpulan: Penelitian ini menyarankan perlu kebijakan pengaturan konten media informasi sebagai media promosi citra tubuh positif. Perlu pembentukan peer education untuk mencegah perilaku seksual berisiko pranikah.

Kata Kunci: remaja; usia pubertas; citra tubuh; perilaku seksual pranikah

\section{PUSTAKA}

1. Hayward C, editor. Gender differences at puberty. Cambridge University Press; 2003 Jul 31.

2. Carlos S, Osorio A, Calatrava M, Lopez-del Burgo C, Ruiz-Canela M, de Irala J. Project YoUrlIFE (What Young People think and Feel about relationships, love, sexuality, and related risk Behavior): cross-sectional and longitudinal Protocol. Frontiers in public health. 2016 Feb 22;4:28.

3. Brener N, Lowry R, Kann I, Kolbe I, Lehnherr J. Trends in sexual risk behaviors among high school students--United States 1991-2001. MMWR. Morbidity and mortality weekly report. 2002;51(38):856-9.

4. BKKBN. Profil Pendataan Keluarga Tahun 2011. Jakarta: Badan Kependudukan dan Keluarga Berencana Nasional Direktorat Pelaporan dan Statistik. 2011.

5. SKKR. Survei Kesehatan Reproduksi Remaja Propinsi DIY. Yogyakarta: Badan Pemberdayaan Perempuan dan Masyarakat Propinsi Daerah Istimewa Yogyakarta dan PT.Cendekia Utama. 2011.

6. Baams L, Dubas JS, Overbeek G, Van Aken MA. Transitions in body and behavior: a meta-analytic study on the relationship between pubertal development and adolescent sexual behavior. 
Journal of Adolescent Health. 2015 Jun 1;56(6):586-98.

7. Lee CT, Tsai MC, Lin CY, Strong C. Longitudinal effects of self-report pubertal timing and Menarcheal age on adolescent psychological and behavioral outcomes in female youths from Northern Taiwan. Pediatrics \& Neonatology. 2016 Aug 1;58(4):313-20.

8. Winter VR, Satinsky S. Body appreciation, sexual relationship status, and protective sexual behaviors in women. Body Image. 2014 Jan 1;11(1):36-42.

9. Pujols $\mathrm{Y}$, Meston CM, Seal BN. The association between sexual satisfaction and body image in women. The journal of sexual medicine. $2010 \mathrm{Feb}$ 1;7(2pt2):905-16.

10. Vasilenko SA, Ram N, Lefkowitz ES. Body image and first sexual intercourse in late adolescence. Journal of adolescence. 2011 Apr 1;34(2):327-35.

11. Greenhill NM. Examining Whether Body Image Dissatisfaction is a Predictor of Risky Sexual Behavior. 2015.

12. L'Engle KL, Brown JD, Kenneavy K. The mass media are an important context for adolescents' sexual behavior. Journal of Adolescent Health. 2006 Mar 1;38(3):186-92.

13. Petersen AC, Crockett L, Richards M, Boxer A. A self-report measure of pubertal status: Reliability, validity, and initial norms. Journal of Youth and Adolescence. 1988 Apr 1;17(2):117-33.

14. Reed DL, Thompson JK, Brannick MT, Sacco WP. Development and validation of the physical appearance state and trait anxiety scale (PASTAS).
Journal of Anxiety Disorders. 1991 Jan 1;5(4):323-32.

15. Sales, J. M., Milhausen, R. R., Wingood, G. M., DiClemente, R. J., Salazar, L. F. \& Crosby,

16. Sales JM, Milhausen RR, Wingood GM, DiClemente RJ, Salazar LF, Crosby RA. Validation of a parent-adolescent communication scale for use in STD/HIV prevention interventions. Health Education \& Behavior. 2008 Jun;35(3):332-45.

17. BKKBN. Pedoman tata cara pencacatan dan pelaporan pendataan keluarga. Jakarta: Badan Kependudukan dan Keluarga Berencana Nasional Direktorat Pelaporan dan Statistik. 2007.

18. De Genna NM, Larkby C, Cornelius MD. Pubertal timing and early sexual intercourse in the offspring of teenage mothers. Journal of youth and adolescence. 2011 Oct 1;40(10):1315-28.

19. Gillen MM, Lefkowitz ES, Shearer CL. Does body image play a role in risky sexual behavior and attitudes?. Journal of Youth and Adolescence. 2006 Apr 1;35(2):230-42.

20. Cookingham LM, Ryan GL. The impact of social media on the sexual and social wellness of adolescents. Journal of pediatric and adolescent gynecology. 2015 Feb 1;28(1):2-5.

21. Sudirman, R. M. \& Pradjatmo, H. Peran teman sebaya dan paparan media pornografi terhadap perilaku seksual remaja di sekolah menengah kejuruan tunas bangsa kabupaten subang. Universitas Gadjah Mada. 2015.

22. Sinaga ES. Faktor-Faktor yang Mempengaruhi Perilaku Seks Pranikah pada Mahasiswa Akademi Kesehatan X di Kabupaten Lebak. Archive of Community Health. 2015;2(1). 